\title{
Erythromycin induced neuroprotection during prolonged deep hypothermic circulatory arrest in an acute porcine model
}

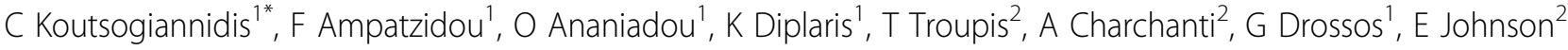 \\ From 23rd World Congress of the World Society of Cardio-Thoracic Surgeons \\ Split, Croatia. 12-15 September 2013
}

\section{Background}

The present study assesses whether preconditioning with erythromycin can improve neuronal viability in the neocortex following deep hypothermic circulatory arrest (DHCA) in the porcine model.

\section{Methods}

Piglets were treated with erythromycin $(25 \mathrm{mg} / \mathrm{kg}$, iv $)$ $(\mathrm{n}=8)$ or vehicle $(\mathrm{n}=6)$ and subjected to 75 minutes of DHCA at $18^{\circ} \mathrm{C}, 12$ hours after pretreatment. Three served as normal controls. After gradual rewarming, treatment animals were sacrificed and brains were perfusion-fixed and cryopreserved. Motor cortex was dissected from the left hemisphere and paraffin embedded for histologic staining with hematoxylin and eosin (HE). To assess neuronal damage, HE-stained paraffin sections $(10 \mu \mathrm{m})$ were examined by light microscopic examination at $\times 400$ magnification. Layer $\mathrm{V}$ of the motor cortex was counted. Neuronal injury was recorded when there was evidence of eosinophilic cytoplasm, cytoplasmic vacuolation, cell body shrinkage or nuclear pyknosis. Neuronal injury was scored on a scale of 0-5.

\section{Results}

The peri-operative physiological variables did show significant variations with erythromycin drug treatment. The motor cortex from piglets pretreated with vehicle undergoing DHCA showed diffuse edema. Neurons showed a diffuse loss of Nissl substance, shrinkage of the perikaryon, and nuclear pyknosis with a mean neuronal injury score of $3.74+1.47$. Neuronal injury in the motor

\footnotetext{
* Correspondence: harisdoc76@yahoo.gr

'Cardiothoracic Surgery Department, General Hospital "G. Papanikolaou",

Thessaloniki, Greece

Full list of author information is available at the end of the article
}

cortex was significantly lower in animals pretreated with erythromycin $(2.53+1.22 ; \mathrm{p}<0.01)$. Normal controls showed minimal neuronal injury $(0.42+0.51)$.

\section{Conclusion}

Pharmacologic preconditioning with erythromycin significantly improved neuronal viability in the motor neocortex of piglets undergoing $\mathrm{HCA}$ at $18^{\circ} \mathrm{C}$. These findings suggest a potential clinical strategy of preemptive neuroprotection.

\section{Authors' details}

'Cardiothoracic Surgery Department, General Hospital "G. Papanikolaou",

Thessaloniki, Greece. 'Department of Anatomy, University of Athens Medical School, Athens, Greece.

Published: 11 September 2013

\section{doi:10.1186/1749-8090-8-S1-024}

Cite this article as: Koutsogiannidis et al:: Erythromycin induced neuroprotection during prolonged deep hypothermic circulatory arrest in an acute porcine model. Journal of Cardiothoracic Surgery 2013 8(Suppl 1):O24.

Submit your next manuscript to BioMed Central and take full advantage of:

- Convenient online submission

- Thorough peer review

- No space constraints or color figure charges

- Immediate publication on acceptance

- Inclusion in PubMed, CAS, Scopus and Google Scholar

- Research which is freely available for redistribution

\section{() Biomed Central}

